\title{
THE URINARY EXCRETION OF SODIUM AND POTASSIUM DURING THE PYROGENIC REACTION IN MAN ${ }^{1,2}$
}

\author{
BY WILLOUGHBY LATHEM 3 \\ (From the Veterans Administration Hospital, West Haven, Connecticut, and The Department \\ of Internal Medicine, Yale University School of Medicine, New Haven, Conn.)
}

(Submitted for publication December 7, 1955; accepted May 10, 1956)

Among the mechanisms regulating the renal tubular transport of electrolytes the renal circulation plays an important but as yet imperfectly understood role. An interrelation between renal hemodynamics and sodium reabsorption has been demonstrated (2) in a variety of experimental circumstances associated with renal vasoconstriction (infusions of adrenal medullary hormones [3], neosynephrine [4], and other drugs [5] ; during orthostasis [4], hemorrhage [6]). Whether such an interrelation exists during renal hyperemia is, however, not known. The present study was undertaken in order to examine this problem further. For this purpose a study was made of urinary sodium and potassium excretion during the pyrogenic reaction, a physiologic alteration accompanied by both renal vasoconstriction and vasodilatation (7).

\section{METHOD}

Thirty-two studies were made in 27 convalescent adult male subjects. All subjects were free from cardiovascular or renal disease, none was recovering from a febrile disorder, and all were maintained on a normal hospital diet containing approximately 10 grams of sodium chloride a day. All studies were made in fasting, recumbent subjects during the morning hours, from approximately 8 A.M. until noon, or later as noted.

The effects of the pyrogenic reaction were examined in 16 subjects. In eleven of these studies the clearances of inulin, PAH, sodium and potassium were determined before and following administration of typhoid-paratyphoid vaccine. All 11 subjects were given $500 \mathrm{ml}$. of water by mouth one-half to one hour prior to the test and received an infusion of 5 per cent dextrose in water intravenously at a rate of $5 \mathrm{ml}$. per minute throughout the

1 A preliminary report of this study has appeared in abstract form (1).

2 Supported by grants from The American Heart Association and the Greenwich Health Association and the National Heart Institute, National Institutes of Health, Public Health Service.

3 Present address : Department of Medicine, University of Pittsburgh School of Medicine, Pittsburgh, Pennsylvania. test. Urine was collected every 10 to 30 minutes over a period of approximately 3 hours. Typhoid vaccine (75,000,000 organisms) was administered intravenously at the conclusion of the first 10 to 20 -minute collection period. Blood was collected without stasis at approximately halfhour intervals throughout the test. In order to prevent a rise in body temperature 8 of these subjects were given Aminopyrine on the day prior to the test in a dosage of 0.6 gram every four hours. Three subjects (J. P., E. V. and G. R.) did not receive this medication.

In five subjects the effects of the pyrogenic reaction on sodium and potassium excretion were observed over a five-hour period and measurements of renal hemodynamics were not made. These subjects ingested $500 \mathrm{ml}$. of water one-half to one hour prior to the test and approximately 100 to $200 \mathrm{ml}$. every hour thereafter in order to maintain an adequate urine flow. No intravenous fluids were given. Urine was collected every hour by spontaneous voiding which usually required that the subject stand briefly by the side of the bed. Typhoidparatyphoid vaccine $(75,000,000$ organisms) was administered intravenously at the end of the first hourly collection period. All five subjects were premedicated with Aminopyrine.

Control observations of urinary sodium and potassium excretion were made in 16 studies under conditions similar to those employed in the experimental (pyrogen) studies except that typhoid vaccine was not administered. None of these subjects received Aminopyrine.

In all studies the body temperature was measured orally and the cardiac rate and arterial blood pressure (sphygmomanometer) were determined at frequent intervals. Sodium and potassium content of urine and plasma were determined by an internal standard flame photometer. Inulin was determined by the method of Harrison (8) and PAH by the method of Smith, Finkelstein, Aliminosa, Crawford, and Graber (9).

\section{RESULTS}

\section{Body temperature and subjective response}

In eleven of thirteen subjects premedicated with Aminopyrine the body temperature remained normal following the injection of typhoid vaccine (Tables I and II). These subjects remained asymptomatic throughout the test. In two (J. McN. and R. B.) premedicated and in three 
(J. P., E. V. and G. R.) untreated subjects a chill occurred approximately one to two hours after the administration of vaccine and the oral temperature increased to approximately $100^{\circ} \mathrm{F}$. (Table I). These subjects complained of headache, backache and malaise at the time of the chill.

The arterial blood pressure increased 5-10/ 5-10 mm. $\mathrm{Hg}$ in most subjects, along with an acceleration of cardiac rate (10 to 20 beats per minute), during the initial phase of the pyrogenic reaction (one to two hours) and remained elevated throughout the study (Table I).

\section{Renal hemodynamics}

The renal circulatory adjustments accompanying the pyrogenic reaction were similar to those reported in previous studies $(10,11)$. Renal plasma flow (PAH clearance) increased (on the average, 40 per cent) one and one-half to two hours following administration of typhoid vaccine in all eleven subjects in whom renal hemodynamics were studied (Table I). Glomerular filtration rate (inulin clearance) did not change from resting values during hyperemia (except in A. $R$. in whom there was a slight decrement and in $\mathrm{E}$. V. in whom

TABLE I

Renal function and urinary electrolyte excretion in eleven normal subjects during the pyrogenic reaction *

\begin{tabular}{|c|c|c|c|c|c|c|c|c|c|c|c|}
\hline Subject & \multirow{2}{*}{$\begin{array}{l}\text { Elapsed } \\
\text { time } \\
\text { min. }\end{array}$} & \multirow{2}{*}{ Temp. } & \multirow{2}{*}{$\underset{m m .}{\mathbf{B . P}} \dot{\mathbf{H} g}$} & \multirow{2}{*}{$\underset{m E q . / L .}{\operatorname{Plasma} N_{.}}$} & \multirow{2}{*}{$\underset{m E q . / L .}{\operatorname{Plasma~K}}$} & \multirow{2}{*}{$\underset{m l . / m i n}{C_{\text {in }}}$} & \multirow{2}{*}{$\underset{m l .}{C_{p a h}}$} & \multirow{2}{*}{$\begin{array}{l}\text { FF } \\
\%\end{array}$} & \multirow{2}{*}{$\underset{m l . / m i n}{\mathrm{~V}}$} & \multirow{2}{*}{$\underset{\mu E q . / \min .}{\mathrm{U}_{\mathrm{naV}}}$} & \multirow{2}{*}{$\underset{\mu E q . / \min }{U_{k} V}$} \\
\hline S.A. & & & & & & & & & & & \\
\hline $\begin{array}{l}\text { W. G. W. } \\
45\end{array}$ & $\begin{array}{r}46 \\
79 \\
104 \\
127 \\
147 \\
170\end{array}$ & $97^{8}$ & $\begin{array}{l}104 / 62 \\
106 / 50\end{array}$ & $\begin{array}{r}137.8 \\
138.1\end{array}$ & 4.42 & $\begin{array}{l}115 \\
105 \\
108 \\
110 \\
111 \\
108\end{array}$ & $\begin{array}{l}545 \\
468 \\
507 \\
572 \\
769 \\
813\end{array}$ & $\begin{array}{l}21 \\
22 \\
21 \\
19 \\
14 \\
13\end{array}$ & $\begin{array}{l}4.3 \\
1.5 \\
2.0 \\
3.5 \\
2.1 \\
3.2\end{array}$ & $\begin{array}{l}63.4 \\
59.2 \\
22.4 \\
50.4 \\
80.2 \\
54.8\end{array}$ & $\begin{array}{l}67.0 \\
56.8 \\
39.3 \\
31.9 \\
34.5 \\
51.1\end{array}$ \\
\hline${ }_{32}^{\mathrm{J}} \stackrel{\mathrm{Da}}{2.16}$ & $\begin{array}{r}44 \\
75 \\
102 \\
127 \\
151 \\
169 \\
188\end{array}$ & $\begin{array}{l}97^{2} \\
97^{4}\end{array}$ & $\begin{array}{l}110 / 80 \\
112 / 90 \\
134 / 90 \\
146 / 90\end{array}$ & $\begin{array}{l}136.0 \\
136.4 \\
134.5 \\
136.8\end{array}$ & $\begin{array}{l}4.12 \\
4.20 \\
3.65 \\
3.60\end{array}$ & $\begin{array}{l}150 \\
134 \\
134 \\
154 \\
161 \\
162 \\
149\end{array}$ & $\begin{array}{r}735 \\
664 \\
599 \\
752 \\
1,042 \\
1,173 \\
1,052\end{array}$ & $\begin{array}{l}20 \\
20 \\
22 \\
20 \\
15 \\
14 \\
14\end{array}$ & $\begin{array}{l}7.1 \\
4.2 \\
0.6 \\
0.6 \\
2.5 \\
5.8 \\
8.9\end{array}$ & $\begin{array}{r}142.8 \\
114.2 \\
71.6 \\
108.2 \\
191.4 \\
158.5 \\
134.8\end{array}$ & $\begin{array}{r}101.0 \\
80.0 \\
57.8 \\
42.4 \\
45.4 \\
68.8 \\
87.0\end{array}$ \\
\hline$\underset{33}{\text { W. R. W. }} \underset{1.91}{\text { W. }}$ & $\begin{array}{r}48 \\
82 \\
99 \\
114 \\
131 \\
143 \\
158\end{array}$ & $\begin{array}{l}97^{2} \\
97^{0}\end{array}$ & $\begin{array}{l}110 / 72 \\
110 / 80\end{array}$ & $\begin{array}{l}139.6 \\
136.5\end{array}$ & $\begin{array}{l}4.20 \\
4.05\end{array}$ & $\begin{array}{l}132 \\
105 \\
119 \\
111 \\
134 \\
135 \\
140\end{array}$ & $\begin{array}{r}723 \\
540 \\
776 \\
1,059 \\
1,256 \\
1,225 \\
1,232\end{array}$ & $\begin{array}{l}18 \\
19 \\
15 \\
11 \\
11 \\
11 \\
11\end{array}$ & $\begin{array}{r}11.2 \\
3.8 \\
0.8 \\
0.9 \\
1.4 \\
1.2 \\
1.5\end{array}$ & $\begin{array}{r}96.7 \\
77.7 \\
57.2 \\
100.6 \\
81.2 \\
102.3 \\
113.9\end{array}$ & $\begin{array}{l}96.9 \\
62.0 \\
61.4 \\
95.2 \\
56.9 \\
58.0 \\
61.7\end{array}$ \\
\hline $24^{\text {S. P. }} 1.95$ & $\begin{array}{r}54 \\
86 \\
109 \\
154 \\
168 \\
181\end{array}$ & $\begin{array}{l}97^{\circ} \\
97^{2} \\
97^{2}\end{array}$ & $\begin{array}{l}90 / 58 \\
90 / 58\end{array}$ & $\begin{array}{l}135.5 \\
137.2 \\
136.5\end{array}$ & $\begin{array}{l}4.06 \\
3.80 \\
3.63\end{array}$ & $\begin{array}{l}161 \\
153 \\
170 \\
168 \\
161 \\
168\end{array}$ & $\begin{array}{r}752 \\
668 \\
777 \\
903 \\
1,041 \\
1,206\end{array}$ & $\begin{array}{l}21 \\
23 \\
22 \\
18 \\
15 \\
14\end{array}$ & $\begin{array}{l}0.8 \\
2.1 \\
2.0 \\
6.8 \\
9.7 \\
9.8\end{array}$ & $\begin{array}{r}29.0 \\
15.0 \\
12.1 \\
65.0 \\
137.5 \\
161.5\end{array}$ & $\begin{array}{l}99.5 \\
89.0 \\
77.6 \\
60.1 \\
43.8 \\
46.9\end{array}$ \\
\hline$\underset{37}{\mathrm{~J} .} \mathrm{McN}_{1.64}$ & $\begin{array}{r}72 \\
102 \\
123 \\
138 \\
152 \\
168 \\
183\end{array}$ & $\begin{array}{r}98^{\circ} \\
100^{2}\end{array}$ & $\begin{array}{l}102 / 50 \\
106 / 58 \\
108 / 58 \\
120 / 60\end{array}$ & $\begin{array}{l}133.4 \\
130.0 \\
131.2 \\
132.0\end{array}$ & $\begin{array}{l}4.25 \\
3.92 \\
3.70 \\
\\
3.45\end{array}$ & $\begin{array}{r}108 \\
159 \\
116 \\
110 \\
108 \\
96 \\
103\end{array}$ & $\begin{array}{r}756 \\
1,101 \\
1,080 \\
1,036 \\
1,055 \\
968 \\
1,016\end{array}$ & $\begin{array}{l}14 \\
14 \\
15 \\
11 \\
10 \\
10 \\
10\end{array}$ & $\begin{array}{l}0.6 \\
0.7 \\
0.9 \\
1.3 \\
1.8 \\
2.3 \\
3.1\end{array}$ & $\begin{array}{r}11.1 \\
22.2 \\
10.2 \\
6.2 \\
6.4 \\
5.5 \\
5.5\end{array}$ & $\begin{array}{r}73.0 \\
101.5 \\
70.9 \\
70.9 \\
79.9 \\
76.4 \\
82.1\end{array}$ \\
\hline
\end{tabular}

* In each subject the initial values for renal hemodynamics and electrolyte excretion are the averages of three periods. All other values represent single determinations. The elapsed times are in reference to the beginning of the first collection period. Typhoid vaccine was administered intravenously at the end of the first collection period (10 to 20 minutes after the beginning of the test). All subjects except J. P., E. V., and G. R. were premedicated with Aminopyrine. Abbreviations are as follows: S.A. = body surface area $\left(\mathrm{M}^{2}\right)$, Temp. = body temperature (oral), B.P. = arterial blood pressure, $C_{i n}=$ inulin clearance-glomerular filtration rate ( $\left.\mathrm{ml} . / \mathrm{min}.\right), \mathrm{C}_{\mathrm{pah}}=$ p-aminohippurate clearancerenal plasma flow (ml./min.), FF = filtration fraction $-C_{i n} / C_{p a h}(\%), V=$ urine flow $(\mathrm{ml} . / \mathrm{min}),. U_{\mathrm{na}} V=u r i n a r y$ sodium output ( $\mu \mathrm{Eq} . / \mathrm{min}.), \mathrm{U}_{\mathbf{k}} \mathrm{V}=$ urinary potassium output ( $\mu \mathrm{Eq} . / \mathrm{min}$.). 
TABLE I-Continued

\begin{tabular}{|c|c|c|c|c|c|c|c|c|c|c|c|c|}
\hline \multicolumn{2}{|c|}{ Subject } & \multirow{2}{*}{$\begin{array}{c}\text { Elapsed } \\
\text { time } \\
\text { min. }\end{array}$} & \multirow{2}{*}{ Temp. } & \multirow{2}{*}{$\underset{m m \cdot \dot{H} \boldsymbol{g}}{\mathbf{B} \cdot \dot{P}}$} & \multirow{2}{*}{$\underset{m E q . / L .}{\text { Plasma }}$} & \multirow{2}{*}{$\begin{array}{l}\text { Plasma K } \\
m E q . / L .\end{array}$} & \multirow{2}{*}{$\underset{m l . / m i n .}{\mathrm{Cin}_{\mathrm{in}}}$} & \multirow{2}{*}{${ }_{m l .}^{C}$ Ppeh $_{\text {min }}}$. & \multirow{2}{*}{$\underset{\%}{\mathrm{FF}}$} & \multirow{2}{*}{$\underset{m l . / m i n .}{\mathbf{V}}$} & \multirow{2}{*}{$\underset{\mu E q . / m i n .}{U_{n, V}}$} & \multirow{2}{*}{${ }_{\mu E q . / m i n}^{U_{k} V}$} \\
\hline$\overline{\text { Age }}$ & $\overline{\text { S.A. }}$ & & & & & & & & & & & \\
\hline & 2.01 & $\begin{array}{r}56 \\
84 \\
116 \\
138 \\
152 \\
168\end{array}$ & $\begin{array}{l}97^{\circ} \\
98^{4}\end{array}$ & $\begin{array}{l}118 / 74 \\
132 / 88\end{array}$ & $\begin{array}{l}132.5 \\
135.7\end{array}$ & $\begin{array}{r}4.45 \\
3.90 \\
3.95\end{array}$ & $\begin{array}{l}143 \\
133 \\
132 \\
126 \\
135 \\
125\end{array}$ & $\begin{array}{l}629 \\
696 \\
788 \\
856 \\
816 \\
734\end{array}$ & $\begin{array}{l}23 \\
19 \\
17 \\
15 \\
17 \\
17\end{array}$ & $\begin{array}{r}6.1 \\
4.8 \\
8.2 \\
10.2 \\
9.6 \\
7.8\end{array}$ & $\begin{array}{l}26.0 \\
11.9 \\
27.9 \\
40.0 \\
35.6 \\
24.5\end{array}$ & $\begin{array}{l}62.1 \\
49.7 \\
44.4 \\
39.6 \\
44.5 \\
49.6\end{array}$ \\
\hline & B. 1.90 & $\begin{array}{r}45 \\
71 \\
92 \\
118 \\
141 \\
159 \\
179\end{array}$ & $\begin{array}{l}97^{4} \\
99^{2}\end{array}$ & $\begin{array}{l}128 / 78 \\
140 / 82\end{array}$ & $\begin{array}{r}135.5 \\
135.3\end{array}$ & $\begin{array}{l}3.85 \\
3.68\end{array}$ & $\begin{array}{l}161 \\
133 \\
171 \\
199 \\
180 \\
178 \\
158\end{array}$ & $\begin{array}{r}797 \\
640 \\
822 \\
998 \\
1,061 \\
1,294 \\
1,279\end{array}$ & $\begin{array}{l}20 \\
21 \\
21 \\
20 \\
17 \\
14 \\
12\end{array}$ & $\begin{array}{r}10.9 \\
4.7 \\
0.6 \\
0.9 \\
4.0 \\
2.7 \\
10.6\end{array}$ & $\begin{array}{l}45.3 \\
44.9 \\
45.6 \\
79.4 \\
70.3 \\
57.0 \\
45.3\end{array}$ & $\begin{array}{r}52.1 \\
28.0 \\
8.6 \\
11.5 \\
55.2 \\
62.0 \\
72.5\end{array}$ \\
\hline & ${ }^{R}{ }_{1.82}$ & $\begin{array}{r}26 \\
43 \\
73 \\
95 \\
117 \\
143 \\
164 \\
183\end{array}$ & $\begin{array}{l}98^{\circ} \\
98^{\circ}\end{array}$ & $\begin{array}{l}140 / 90 \\
140 / 90\end{array}$ & $\begin{array}{r}137.1 \\
138.6\end{array}$ & $\begin{array}{l}3.98 \\
3.78\end{array}$ & $\begin{array}{r}112 \\
84 \\
97 \\
98 \\
101 \\
96 \\
96 \\
90\end{array}$ & $\begin{array}{l}549 \\
434 \\
475 \\
513 \\
525 \\
708 \\
817 \\
740\end{array}$ & $\begin{array}{l}20 \\
20 \\
19 \\
19 \\
19 \\
14 \\
12 \\
12\end{array}$ & $\begin{array}{r}10.8 \\
8.3 \\
4.2 \\
2.2 \\
5.4 \\
7.4 \\
6.9 \\
2.5\end{array}$ & $\begin{array}{r}118.8 \\
95.0 \\
63.8 \\
30.5 \\
55.6 \\
106.5 \\
158.0 \\
181.0\end{array}$ & $\begin{array}{l}75.4 \\
69.1 \\
50.8 \\
39.0 \\
27.3 \\
24.1 \\
31.7 \\
46.5\end{array}$ \\
\hline & 2.24 & $\begin{array}{r}35 \\
59 \\
83 \\
113 \\
144 \\
162 \\
183\end{array}$ & 974 & $\begin{array}{l}118 / 74 \\
120 / 80\end{array}$ & $\begin{array}{r}137.8 \\
137.4\end{array}$ & $\begin{array}{l}3.80 \\
3.70\end{array}$ & $\begin{array}{l}151 \\
141 \\
129 \\
140 \\
145 \\
131 \\
115\end{array}$ & $\begin{array}{r}813 \\
819 \\
700 \\
741 \\
1,004 \\
1,146 \\
1,122\end{array}$ & $\begin{array}{l}19 \\
17 \\
18 \\
19 \\
14 \\
11 \\
10\end{array}$ & $\begin{array}{l}6.0 \\
9.7 \\
3.4 \\
1.2 \\
2.8 \\
3.5 \\
2.3\end{array}$ & $\begin{array}{l}113.8 \\
143.5 \\
140.0 \\
141.6 \\
325.0 \\
384.0 \\
208.0\end{array}$ & $\begin{array}{l}44.5 \\
46.6 \\
36.6 \\
32.8 \\
34.5 \\
48.6 \\
70.8\end{array}$ \\
\hline $31^{E}$ & ${ }^{V} \cdot 1.87$ & $\begin{array}{r}36 \\
66 \\
98 \\
123 \\
140 \\
157 \\
172\end{array}$ & $100^{4}$ & $118 / 72$ & $\begin{array}{r}139.0 \\
138.3\end{array}$ & $\begin{array}{l}4.21 \\
4.10\end{array}$ & $\begin{array}{l}137 \\
122 \\
128 \\
119 \\
119 \\
140 \\
149\end{array}$ & $\begin{array}{l}640 \\
623 \\
608 \\
618 \\
656 \\
812 \\
909\end{array}$ & $\begin{array}{l}21 \\
20 \\
19 \\
19 \\
18 \\
17 \\
15\end{array}$ & $\begin{array}{l}7.5 \\
9.2 \\
3.5 \\
1.4 \\
1.4 \\
2.2 \\
2.3\end{array}$ & $\begin{array}{l}220.2 \\
271.2 \\
289.0 \\
220.0 \\
204.6 \\
287.5 \\
317.0\end{array}$ & $\begin{array}{r}109.1 \\
91.6 \\
78.4 \\
69.6 \\
63.0 \\
65.8 \\
70.8\end{array}$ \\
\hline${ }_{32}^{G}$ & ${ }^{R} .01$ & $\begin{array}{r}34 \\
66 \\
97 \\
125 \\
141 \\
159 \\
175\end{array}$ & $\begin{array}{l}97^{8} \\
99^{4}\end{array}$ & $\begin{array}{l}124 / 74 \\
120 / 64\end{array}$ & $\begin{array}{l}136.6 \\
136.3\end{array}$ & $\begin{array}{l}3.98 \\
3.90\end{array}$ & $\begin{array}{r}118 \\
62 \\
100 \\
117 \\
156 \\
112 \\
118\end{array}$ & $\begin{array}{r}645 \\
648 \\
595 \\
534 \\
1,018 \\
840 \\
967\end{array}$ & $\begin{array}{l}18 \\
10 \\
17 \\
22 \\
15 \\
13 \\
12\end{array}$ & $\begin{array}{r}12.1 \\
7.6 \\
1.2 \\
1.1 \\
1.2 \\
0.7 \\
1.1\end{array}$ & $\begin{array}{r}215.2 \\
217.2 \\
104.1 \\
116.0 \\
144.3 \\
41.6 \\
71.0\end{array}$ & $\begin{array}{r}141.8 \\
133.5 \\
107.0 \\
80.6 \\
89.9 \\
85.8 \\
113.0\end{array}$ \\
\hline
\end{tabular}

it increased). In nine subjects the hyperemic phase was preceded by a transient reduction in renal plasma flow which occurred one to two hours following injection of the vaccine (average change, 13 per cent). In seven of these subjects a transient decrement (11 to 21 per cent; average change, 12 per cent) in glomerular filtration rate also occurred at this time; in the remaining two (W. G. W. and S. P.) the filtration rate did not change. The FF tended to remain the same or to increase slightly at this time. In two subjects (J. McN. and G. P.) neither glomerular filtration nor renal plasma flow changed during the latent period prior to hyperemia.
Urine flow

Urine flow decreased one to two hours following administration of the vaccine in eleven of sixteen subjects (V, Tables $I$ and II). In the remainder (S. P., J. McN., G. P., W. L. and F. W.) urine volume was sustained or increased at this time. The reduction in urine flow was always accompanied by a fall in glomerular filtration rate in those studies in which renal hemodynamics were measured (Table I). The decrement in urine flow exceeded the change in filtration in all. In three studies (S. P., J. McN., and G. P.) glomerular filtration rate did not change prior to hyperemia and 
urine volume increased or remained constant. During the later or hyperemic phase of the pyrogenic reaction ( 2 to 5 hours) no systematic change in urine volume was observed, although flow returned towards resting levels if previously depressed. At this time glomerular filtration returned to initial levels. No difference was noted between afebrile and febrile subjects during either the vasoconstrictive or hyperemic phases.

\section{Sodium excretion}

The changes in urinary sodium output were variable. During the initial phase of the pyrogenic reaction (one to two hours following administration of the vaccine) sodium excretion diminished transiently ( 32 to 93 per cent) in 9 of 16 subjects $\left(\mathrm{U}_{\mathrm{na}} \mathrm{V}, \mathrm{Tables} \mathrm{I}\right.$ and $\left.\mathrm{II}\right)$. In other studies sodium output increased (four) or remained unchanged (three) at this time. These alterations were not significant when compared to control subjects and could not be correlated with changes in renal hemodynamics. Although a reduction in glomerular filtration rate accompanied the decrement in sodium output in four of seven studies (J. Da., W. R. W., A. R., and G. R.), sodium excretion increased in two subjects (E. V. and J. P.) and remained unchanged in one (R. B.) despite a fall in glomerular filtration rate. Moreover, in W. G. W., G. P. and S. P. sodium output fell 72, 54 , and 48 per cent, respectively, without a significant change in glomerular filtration. There was no correlation between the changes in sodium excretion and renal plasma flow.

During the second to fifth hour following ad-

TABLE II

Urinary electrolyte excretion in five normal subjects during the pyrogenic reaction *

\begin{tabular}{|c|c|c|c|c|c|c|c|c|}
\hline \multicolumn{2}{|c|}{ Subject } & \multirow{2}{*}{$\begin{array}{l}\text { Elapsed } \\
\text { time } \\
\text { min. }\end{array}$} & \multirow{2}{*}{ Temp. } & \multirow{2}{*}{$\begin{array}{c}\text { Plasma Na } \\
m E q . / L .\end{array}$} & \multirow{2}{*}{$\underset{m E q . / L .}{\operatorname{Plasma} \mathrm{K}}$} & \multirow{2}{*}{$\underset{m l . / m i n}{\mathrm{~V}}$} & \multirow{2}{*}{$\underset{\mu E q . / m i n}{\mathrm{UnV}_{\mathrm{na}}}$} & \multirow{2}{*}{$\underset{\mu E q . / \min }{U_{k} V}$} \\
\hline Age & S.A. & & & & & & & \\
\hline & 1.92 & $\begin{array}{r}56 \\
118 \\
181 \\
237 \\
299 \\
361 \\
417\end{array}$ & $\begin{array}{l}97^{\circ} \\
98^{\circ} \\
98^{\circ}\end{array}$ & $\begin{array}{r}137.8 \\
137.6\end{array}$ & 4.50 & $\begin{array}{l}0.7 \\
0.7 \\
0.6 \\
1.0 \\
2.3 \\
1.5 \\
1.5\end{array}$ & $\begin{array}{l}33.0 \\
40.6 \\
37.3 \\
81.7 \\
85.6 \\
91.2 \\
94.6\end{array}$ & $\begin{array}{r}27.0 \\
40.8 \\
45.9 \\
73.7 \\
143.9 \\
110.9 \\
93.7\end{array}$ \\
\hline & 1.83 & $\begin{array}{r}60 \\
124 \\
183 \\
241 \\
316 \\
371 \\
423\end{array}$ & $97^{8}$ & 129.5 & 3.95 & $\begin{array}{l}0.7 \\
1.1 \\
2.0 \\
3.2 \\
2.0 \\
1.3 \\
3.6\end{array}$ & $\begin{array}{l}28.1 \\
66.7 \\
40.1 \\
50.2 \\
62.8 \\
91.1 \\
56.9\end{array}$ & $\begin{array}{r}59.1 \\
80.8 \\
52.0 \\
76.6 \\
112.4 \\
88.3 \\
65.8\end{array}$ \\
\hline $46^{I}$ & 1.86 & $\begin{array}{r}65 \\
121 \\
182 \\
262 \\
303 \\
366\end{array}$ & 974 & $\begin{array}{r}137.6 \\
131.8\end{array}$ & 4.15 & $\begin{array}{l}3.2 \\
4.8 \\
2.0 \\
4.1 \\
4.6 \\
5.1\end{array}$ & $\begin{array}{r}143.6 \\
212.0 \\
97.4 \\
236.5 \\
153.6 \\
107.3\end{array}$ & $\begin{array}{r}107.6 \\
132.1 \\
78.6 \\
65.0 \\
131.4 \\
249.0\end{array}$ \\
\hline 20 & 2.14 & $\begin{array}{r}66 \\
145 \\
197 \\
252 \\
306 \\
372\end{array}$ & $98^{\circ}$ & & & $\begin{array}{r}8.8 \\
7.1 \\
0.3 \\
5.5 \\
12.7 \\
7.2\end{array}$ & $\begin{array}{r}68.4 \\
55.4 \\
4.8 \\
32.1 \\
48.0 \\
54.4\end{array}$ & $\begin{array}{r}35.9 \\
52.0 \\
10.5 \\
79.9 \\
137.5 \\
100.8\end{array}$ \\
\hline & 2.20 & $\begin{array}{r}68 \\
139 \\
198 \\
252 \\
309 \\
369\end{array}$ & 974 & & & $\begin{array}{r}5.5 \\
7.1 \\
3.0 \\
10.9 \\
9.4 \\
8.5\end{array}$ & $\begin{array}{r}101.4 \\
77.4 \\
31.2 \\
85.5 \\
108.7 \\
49.4\end{array}$ & $\begin{array}{r}221.5 \\
176.7 \\
48.5 \\
84.2 \\
73.1 \\
117.9\end{array}$ \\
\hline
\end{tabular}

* Each value represents a single determination. Typhoid vaccine was administered at the end of the first period. All subjects were premedicated with Aminopyrine. Abbreviations are as in Table I. 
TABLE III

Mean plasma and urinary electrolyte values in sixteen control subjects and in sixteen subjects before and during the pyrogenic reaction*

\begin{tabular}{|c|c|c|c|c|}
\hline \multirow[b]{2}{*}{ Hours } & \multicolumn{2}{|c|}{ Plasma } & \multicolumn{2}{|c|}{ Urine } \\
\hline & $\underset{m E q . / L .}{N_{2}}$ & $\underset{m E q . / L .}{\mathrm{K}}$ & $\underset{\mu E q . / \min .}{U_{\mathrm{na}} \mathrm{V}}$ & $\underset{\mu E q . / \min .}{U_{k} V}$ \\
\hline \multicolumn{5}{|c|}{ Control subjects } \\
\hline $\begin{array}{l}0-1 \\
2-3\end{array}$ & $\begin{array}{l}138.0 \pm 1.0 \\
139.5 \pm 0.7\end{array}$ & $\begin{array}{l}4.29 \pm 0.13 \\
4.17 \pm 0.14\end{array}$ & $\begin{array}{l}103.3 \pm 18.8 \\
153.0 \pm 21.4\end{array}$ & $\begin{array}{l}72.7 \pm 8.1 \\
77.0 \pm 6.0\end{array}$ \\
\hline \multicolumn{5}{|c|}{ Experimental (pyrogen) subjects } \\
\hline $\begin{array}{l}0-1 \\
2-3\end{array}$ & $\begin{array}{l}136.0 \pm 0.7 \\
136.7 \pm 0.6\end{array}$ & $\begin{array}{l}4.12 \pm 0.05 \\
3.76 \pm 0.05\end{array}$ & $\begin{array}{r}91.6 \pm 16.4 \\
119.0 \pm 24.4\end{array}$ & $\begin{array}{l}85.9 \pm 11.8 \\
64.1 \pm 3.7\end{array}$ \\
\hline
\end{tabular}

* Each value is the mean and standard error of the mean for all subjects in the control and experimental groups, respectively. The time in hours is in reference to the beginning of the first collection period. The experimental subjects receiving typhoid vaccine are those listed in Tables I and II. The mean values for this group during the first hour represent resting values prior to an effect of the pyrogenic reaction. The 2- to 3-hour values are those obtained at the time of intrarenal hyperemia. Abbreviations are as shown in Table I.

ministration of the vaccine, at the time of renal hyperemia, sodium output did not change consistently. The mean excretion at this time exceeded resting levels (by more than 10 per cent) in 10 of 16 subjects and was less than or equal to these values in the remainder. The mean change for the entire group of 16 subjects during the third hour ${ }^{4}$ was not significant when compared to resting values $(t=1.55 ;<.50>.10)$ or when compared to the mean spontaneous changes observed over a similar time interval in control subjects $(t=$ $0.88 ; p<.50>.10$ ) (Table III). No difference was noted between febrile and afebrile subjects. The sodium content of plasma did not change significantly $(t=1.64 ; p<.50>.10)$ (Table III).

Potassium excretion decreased (20 to 46 per cent) one to two hours following administration of typhoid vaccine in nine of eleven subjects in whom renal hemodynamics were measured $\left(\mathrm{U}_{\mathrm{k}} \mathrm{V}\right.$, Table I). Potassium output increased in J. McN. and remained unchanged in S. P. at this time. Although the reduction in potassium excretion was usually accompanied by intrarenal vasoconstriction, this change occurred independently of alterations in glomerular filtration rate and in one instance (G. P.) occurred in the absence of a change in renal plasma flow. During hyperemia potassium output remained essentially constant except in J. P., in whom the excretion of this ion in-

4 This time was selected in order to analyze statistically the changes during hyperemia in all 16 subjects. The subjects listed in Table I were not studied beyond the third hour. creased and in S. P. and G. R., in whom it diminished. A similar response was observed in five subjects in whom renal hemodynamics were not studied (Table II). Potassium output fell in three (H. H., D. B., and L. G.) of these subjects, remained unchanged in one (F.W.) and increased in one (W. L.) during the first two to three hours following administration of the vaccine. During the fourth and fifth hours the urinary excretion of this ion increased above resting levels in four of five studies. No difference was observed between febrile and afebrile subjects in either group of subjects.

The mean reduction in potassium output from resting levels in all 16 subjects during the first one to two hours of the pyrogenic reaction was of borderline significance $(t=2.70 ; p<.02>.01)$. This change was not significant when compared to the control group $(t=1.53 ; p<.50>.10)$. During hyperemia the mean potassium output did not differ significantly from resting levels $(t=$ $2.01 ; \mathrm{p}<.10>.05$ ) (Table III), nor was the mean difference significant when compared to spontaneous changes observed in control subjects $(\mathrm{t}=1.53 ; \mathrm{p}<.50>.10)$ (Table III).

The concentration of potassium in plasma decreased during the pyrogenic reaction in 8 of 14 subjects (plasma electrolytes were not measured in two). In the remainder no change was noted. The mean reduction for all 14 subjects, $0.35 \mu \mathrm{Eq}$. per L. (range, 0 to $0.80 \mu \mathrm{Eq}$. per L.), was significant when compared with resting levels $(t=7.0$; $\mathrm{p}<.01$ ) (Table III), but not when compared 
with the mean spontaneous change in control subjects studied during a simliar interval of time $(t=$ $1.97 ; \mathrm{p}<.10>.05$ ) (Table III).

\section{DISCUSSION}

In the present study no definite interrelation was demonstrated between urinary electrolyte excretion and the renal circulatory adjustments attending the pyrogenic reaction. During the initial vasoconstrictive phase of this reaction, when renal plasma flow and glomerular filtration rate were transiently reduced, sodium and potassium output were not altered systematically, nor was there a significant change in the excretion of these ions during the later and more sustained phase of intrarenal hyperemia.

Previous evidence of a relationship between renal hemodynamics and urinary sodium excretion has been obtained in a variety of experimental and clinical conditions which have in common intrarenal vasoconstriction $(2,4,5)$. The mechanism by which sodium excretion is reduced under these conditions is not clear but changes in glomerular filtration rate $(2,7)$ and perhaps in the intrarenal distribution of blood (6) may play a role. Whether changes in filtration are necessary has not been established. It has been suggested that electrolyte reabsorption may be influenced by the rate of blood flow through the kidney $(4,5)$. Although the present study does not support this view, since sodium and potassium excretion remained unchanged during both renal vasoconstriction and hyperemia, further studies are needed in order to evaluate this problem in view of the many physiologic and metabolic alterations elicited during the pyrogenic reaction (12) which might influence electrolyte metabolism and reabsorption independently of renal hemodynamics. The results of this study cannot be interpreted with certainty in terms of the relationship between the renal circulation and tubular function. Whether an interrelation between electrolyte excretion and hyperemia exists under circumstances other than the pyrogenic reaction must be determined. During renal vasodilatation as elicited by intravenous 1-hydrazinophthalazine, urinary sodium excretion is unaltered (13).

Although alterations in renal hemodynamics did not affect electrolyte excretion in the pres- ent study, the reduction in glomerular filtration rate during the vasoconstrictive phase of the pyrogenic reaction appeared to initiate a fall in urine volume, as has been demonstrated previously in man (7), and the urine became more concentrated with respect to sodium and potassium ions. That factors other than a change in filtration contributed to the reduced urine output is suggested by the fact that, once initiated, the antidiuresis tended to persist despite a return of glomerular filtration rate to control levels. These observations differ from those reported recently by Brandt, Ruskin, Zumoff, Castleman, and Zuckerman (14) who describe an increase in the free water clearance of dogs following administration of a bacterial pyrogen derived from pseudomonas.

\section{SUMMARY}

A study was made of the effect of the pyrogenic reaction as elicited by triple typhoid vaccine on the urinary excretion of sodium and potassium in 16 normal human subjects. No systematic change in the excretion of these ions was observed in febrile or afebrile subjects during either the early, transient period of renal vasoconstriction or the late, sustained period of renal hyperemia. A reduction in urine volume occurred during the vasoconstrictive phase in association with a decrement in glomerular filtration rate and the urine became more concentrated with respect to sodium and potassium ions.

\section{ACKNOWLEDGMENT}

The technical assistance of Miss Marion Brazel and Mrs. Frances Kennedy is gratefully acknowledged.

\section{REFERENCES}

1. Lathem, W., Urinary excretion of sodium and potassium during the pyrogenic reaction. J. Clin. Invest., 1954, 33, 951.

2. Selkurt, E. E., Sodium excretion by the mammalian kidney. Physiol. Rev., 1954, 34, 287.

3. Smythe, C. McC., Nickel, J. F., and Bradley, S. E., The effect of epinephrine (USP), l-epinephrine, and $l$-norepinephrine on glomerular filtration rate, renal plasma flow, and the urinary excretion of sodium, potassium, and water in normal man. J. Clin. Invest., 1952, 31, 499.

4. Elkinton, J. R., Crosley, A. P., Jr., Barker, H. G., and Clark, J. K., Alterations in renal hemodynamics and excretion of electrolytes. Federation Proc., 1950, 9, 37. 
5. Nickel, J. F., Smythe, C. McC., Papper, E. M., and Bradley, S. E., A study of the mode of action of the adrenal medullary hormones on sodium, potassium and water excretion in man. J. Clin. Invest., 1954, 33, 1687.

6. Goodyer, A. V. N., and Jaeger, C. A., Renal response to nonshocking hemorrhage. Role of the autonomic nervous system and of the renal circulation. Am. J. Physiol., 1955, 180, 69.

7. Smith, H. W., The Kidney: Structure and Function in Health and Disease. New York, Oxford Univ. Press, 1951.

8. Harrison, H. E., A modification of the diphenylamine method for determination of inulin. Proc. Soc. Exper. Biol. \& Med., 1942, 49, 111.

9. Smith, H. W., Finkelstein, N., Aliminosa, L., Crawford, B., and Graber, M., The renal clearances of substituted hippuric acid derivatives and other aromatic acids in dog and man. J. Clin. Invest., 1945, 24, 388.
10. Bradley, S. E., Chasis, H., Goldring, W., and Smith, H. W., Hemodynamic alterations in normotensive and hypertensive subjects during the pyrogenic reaction. J. Clin. Invest., 1945, 24, 749.

11. Chasis, H., Ranges, H. A., Goldring, W., and Smith, H. W., The control of renal blood flow and glomerular filtration in normal man. J. Clin. Invest., 1938, 17, 683.

12. Bennett, I. L., Jr., and Beeson, P. B., The properties and biologic effects of bacterial pyrogens. Medicine, 1950, 29, 365.

13. Judson, W. E., Hollander, W., Friedman, I. H., Hatcher, J. D., and Halperin, M. H., Studies on congestive failure: The effects of exercise, salt loading and of intravenous apresoline on cardiorenal hemodynamics and the excretion of sodium and water. J. Clin. Invest., 1953, 32, 579.

14. Brandt, J. L., Ruskin, H. D., Zumoff, B., Castleman, L., and Zuckerman, S., Inhibition of renal tubular responsiveness to antidiuretic hormone by pyrogens. Proc. Soc. Exper. Biol. \& Med., 1955, 88, 451. 